Home Page : http://riset.unisma.ac.id/index.php/jki

\title{
MODEL PENDEKATAN EDUCATION OF THE MOTHER COMMUNITY(EMC) DALAM PENCEGAHAN DIARE PADA ANAK DI PEKAPURAN RAYA
}

\author{
Sri Herlina \\ ${ }^{1}$ Program Studi Pendidikan Dokter Fakultas Kedokteran \\ Universitas Islam Malang \\ E-mail : $\underline{\text { lilinskm@gmail.com }}$
}

\begin{abstract}
Abstrak
Morbiditas penyakit diare di negara berkembang merupakan masalah kesehatan masyarakat karena prevalensi masih tinggi terutama untuk anak di bawah lima tahun. Tercatat sebanyak 207 balita yang mengalami diare di Pekapuran Raya. Penelitian ini bertujuan untuk mengetahui manfaat model pendekatan education of the mother community (EMC), khususnya terhadap pengetahuan ibu balita dalam pencegahan diare. Rancangan penelitian quasi eksperimental one group pre post test design dilakukan pada 43 ibu yang memiliki balita dibawah lima tahun di KelurahanPekapuran Raya Banjarmasin. Hasilpre-test dan post-test menunjukkan adanya peningkatan pemahaman ibu balita terhadap pencegahan diare setelah dilakukan kegiatan promosi menggunakan model pendekatan education of the mother community $(\mathrm{p}<0,05)$. Model ini terbukti bermanfaat untuk menyampaikan informasi kesehatan berhubungan denganpencegahan diare pada balita.
\end{abstract}

Kata kunci:diare, pencegahan, model, education of the mother community (EMC)

\begin{abstract}
Morbidity of diarrhea diseases in developing countries is a public healthconcern because the prevalence is still high particularly for children under five years. 207 children recorded had the diarrhea in Pekapuran Raya.This study aims to know the benefits of model approach of education of the mother community (EMC), particularly to the mother'sknowledge on prevention of diarrhea. Quasiexperimental research design one group pre-post test design conducted on 38 mother that have children under five years in Pekapuran Raya Subdistrict of Banjarmasin. The results of pre-test and post-test shows that there is understanding increased the mothers for prevention of diarrhea afterpromotion using model approach of education of the mother community(p <0,05). This model proven to be useful for deliver the healthy information concerning prevention of diarrhea for children.
\end{abstract}

Keywords:diarrhea, prevention, model, education of the mother community (EMC) 


\section{PENDAHULUAN}

Sampai saat ini penyakit diare masih menjadi masalah kesehatan dunia terutama di negara berkembang. Di Indonesia, Penyakit diare merupakan salah satu penyakit yang berbasis lingkungan yang dapat mengancam masyarakat. Hal ini disebabkan masih buruknya kondisi sanitasi dasar, lingkungan fisik, maupun rendahnya perilaku masyarakat untuk hidup bersih dan sehat Akibatnya, jumlah kasus diare meningkat setiap tahun tingginya angka kesakitan dan menimbulkan banyak kematian terutama pada bayi dan balita, serta sering menimbulkan kejadian luar biasa $(\mathrm{KLB})^{(1)}$.

Tingginya curah hujan seringkali terjadi peningkatan kasus diare yang sebagian besar menyerang anak balita maupun dewasa. Diare merupakan gejala dari suatu penyakit atau adanya kelainan di saluran pencernaan, yang menyebabkan frekuensi buang air besar melebihi normal (lebih dari 3 kali sehari) dan tinja yang dikeluarkan biasanya berbentuk lembek/cair bahkan dapat berupa air saja, dengan atau tanpa disertai darah atau lender ${ }^{(2)}$. Data kesehatan menunjukan lebih dari 150.000 orang yang masih memanfaatkan atau mengandalkan air untuk keperluan sehari-hari seperti memasak, cuci, dan kakus (MCK), terutama masyarakat yang bermukim di daerah pinggiran sungai ${ }^{(3)}$. Mengingat bahwa sebagian besar penyakit diare dapat ditularkan melalui air yang terkontaminasi bahan patogen berbahaya maka penyedian air bersih dan pengolahannya sangat penting diperhatikan guna mencegah terjadinya diare.

Setiap tahunnya, 525.000 anak dibawah lima tahun (balita) meninggal akibat diare, menjadikan penyakit ini sebagai penyebab kematian terbanyak kedua pada balita ${ }^{(4)}$.Secara global terdapat 1.7 Miliyar kasus diare pada anak setiap tahunnya Kejadian diare dapat diketahui bahwa proporsi terbesar penderita diare pada balita adalah kelompok umur 6-11 bulan yaitusebesar $21,65 \%{ }^{(5)}$. Angka kejadian diare di Provinsi Kalimantan Selatan berada pada urutan ke-7 dan terjadi sebanyak 22.738 kasus. Angka kejadian ini meningkat 6,9 per 1.000 penduduk menjadi 19,5 per 1.000 penduduk. Tingginya jumlah penderita diare diakibatkan masih banyaknya masyarakat yang belum menerapkan pola hidup sehat dan bersih.

Kematian bayi yang disebabkan diare yaitu sebesar 31,4\% dan kematian anak balita yang disebabkan diare yaitu sebesar $25,2 \%$ pada tahun $2008{ }^{(6)}$. Sebagian besar (70\%-80\%) penderita adalah anak balita dan 1\%-2\% dari penderita akan jatuh ke dalam dehidrasi dan bila tidak ditolong akan meninggal, Sedangkan diare pada balita adalah 2,5/1000 penduduk ${ }^{(7)}$. Tercatat 207 anak yang mengalami diare di Kelurahan Pekapuran Raya Banjarmasin. Data kesehatan dari 26 puskesmas di lima Kecamatan menunjukan bahwa jumlah penderita diare tergolong cukup tinggi yaitu setiap bulannya meningkat rata-rata di atas 80 orang. Angka ini belum termasuk jumlah pasien yang langsung berkunjung ke rumah sakit milik pemerintah maupun swasta ${ }^{(8,6,9)}$.

Pekapuran cukup padat karena berdekatan dengan Pasar Binjai yang merupakan tempat lalu lintas perdagangan antar sungai (terapung) dan darat yang dimanfaatkan untuk sektor industri dan transportasi ${ }^{(10)}$. Saat ini kondisi sungai, sudah sangat memperihatinkan disebabkan adanya kebiasaan penduduk di sepanjang sungai membuang sampah secara langsung ke sungai, sehingga terus menumpuk menyebabkan air sungai semakin kotor dan dangkal ${ }^{(8)}$. Masyarakat 
juga mengeluhkan kualitas air sungai tersebut. Penggunaan air sungai untuk konsumsi dan kebutuhan sehari-hari termasuk membuang kotoran biologis dan non biologis memicu tumbuh kembangnya kuman penyebab diare dan gangguan pencernaan yang berbahaya bagi kesehatan masyarakat ${ }^{(11)}$.Hasil penelitian terhadap sungai Martapura yang dilakukan oleh Fakultas MIPA Universitas Lambung Mangkurat 2007, ditemukan bahwa bakteri Eshericia coli sebanyak 1,6 juta per $100 \mathrm{ml}$ air. Jumlah ini melebihi dari ambang baku mutu yang dipersyaratkan untuk air bersih yaitu $100 \mathrm{sel} / 100$ mili liter air ${ }^{(12)}$.

Mengingat air yang digunakan untuk keperluan hidup masyarakat masih belum memenuhi syarat kesehatan dan tidak dikelola dengan baik, maka diduga insiden penyakit diare yang terjadi juga tinggi, maka perlu dilakukan pencegahan penyakit menggunakan model pendekatan education of the mother community (EMC) yang diharapkan dapat memberikan pemahaman tentang diare, pencegahan dan manajemen balita deteksi diare yang penting diberikan pada ibu balita untuk melindungi anak dari ancaman penyakit diare.Olehsebabitu di pentingnyaperanibudalamkomunitasuntukmencegahdiaremelaluiperilaku hidup bersih dan sehat yang diterapkan dalam bentuk pendidikankesehatan ibu dan balita terutama di Pekapuran Raya.

\section{METODE PENELITIAN}

Penelitian ini bersifat quasi eksperimental one group pre-post test design. Populasi dari study ini adalah seluruh Ibu-ibu yang memiliki balita dibawah 5 tahun di Kelurahan Pekapuran Raya Banjarmasin, Sampel sebanyak 43 responden. Kriteria Inklusi yaitu Ibu balita dibawah 5 tahun dan 3 bulan terakhir mengalami diare, bertempat tinggal disepanjang pinggiran sungai Pekapuran Raya serta bersedia mengikuti keseluruhan kegiatan promosi kesehatan melalui model pendekatan Education of the mother community.Teknik pengambilan sampel secara purporsive sampling. Analisis data dilakukan dengan cara wawancara langsung kepada responden serta berdasarkan hasil observasi lapangan. Instrumen penelitian kuesionerdisertai hasil diskusi serta simulasi peran dideskripsikan (narasi) dari kegiatan EMC secara sistematis. Data pemahaman ibu balita yang diperoleh dianalisis secara statistik dengan uji paried t-test dengan derajat kepercayaan 95\%. Pelaksanaan kegiatan Intervensi dalam Model Education of the mother communitysecara sistematis sebagai berikut:

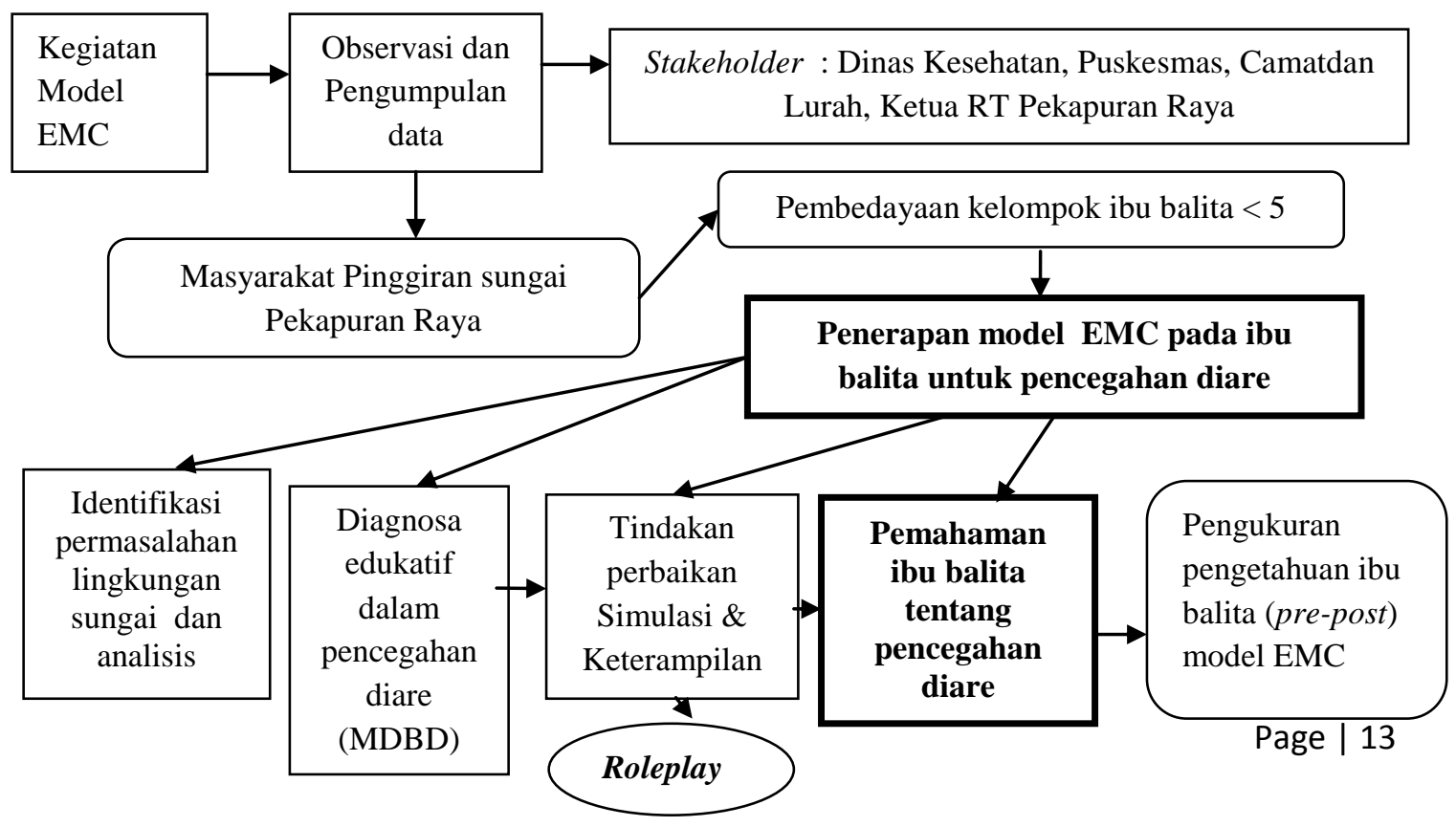




\section{HASIL PENELITIAN}

\section{A. Karakteristik Subjek Penelitian dalam kegiatan EMC}

Karakteristik responden yang terlibat dalam penelitian ini sebanyak 43 responden selengkapnya dapat dilihat pada tabel 1. berikut ini :

Tabel 1. Karakteristik Subjek Penelitian di Kelurahan Pekapuran Raya

\begin{tabular}{lcc}
\hline Karakteristik Subjek & \multicolumn{2}{c}{$\boldsymbol{\sum}$ Frekuensi } \\
\cline { 2 - 3 } Usia & $\mathbf{n = 4 3}$ & $\mathbf{\%}$ \\
$20-25$ tahun & & \\
26-30 tahun & 16 & 37,21 \\
>30 tahun & 22 & 51,16 \\
Tingkat Pendidikan & 5 & 11,63 \\
Sekolah Dasar & 21 & 48,84 \\
SMP & 5 & 11,63 \\
SMA & 15 & 34,88 \\
Perguruan Tinggi & 2 & 4,651 \\
Pekerjaan & & \\
IRT & 38 & 88,37 \\
Karyawan & 2 & 4,651 \\
Penjual & 2 & 4,651 \\
Penjahit & 1 & 2,326 \\
Total & $\mathbf{4 3}$ & $\mathbf{1 0 0}$ \\
& & \\
\hline
\end{tabular}

Berdasarkan Karakteristik responden pada (Tabel 1.) terlihat bahwa responden terbanyak berusia 26-30 tahun sebesar 51,16\% dan pendidikan tertinggi adalah tamatan Sekolah Dasar (SD) sebanyak 48,83\%, dengan pekerjaan terbanyak sebagai ibu rumah tangga (IRT) sebanyak $88,37 \%$.

\section{B. Identifikasi permasalahan lingkungan sungai}

Kegiatan Edukasi kelompok ibu balita diawali dengan perkenalan wilayah Kelurahan Pekapuran Raya. Tujuan identifikasi dan mapping wilayah untuk mengumpulkan informasi terkait permasalahan dilingkungan Pekapuran Raya. Dasar penilaian perilaku negatif dalam diagnosa permasalahan lingkungan di komunitas ini dilihat dari kebiasaan cuci tangan, BAB disungai, perilaku pengolahan air, kebiasaan buang sampah disungai. 
Diagram 1. Hasil Identifikasi perilaku tentang pemanfaatan sungai

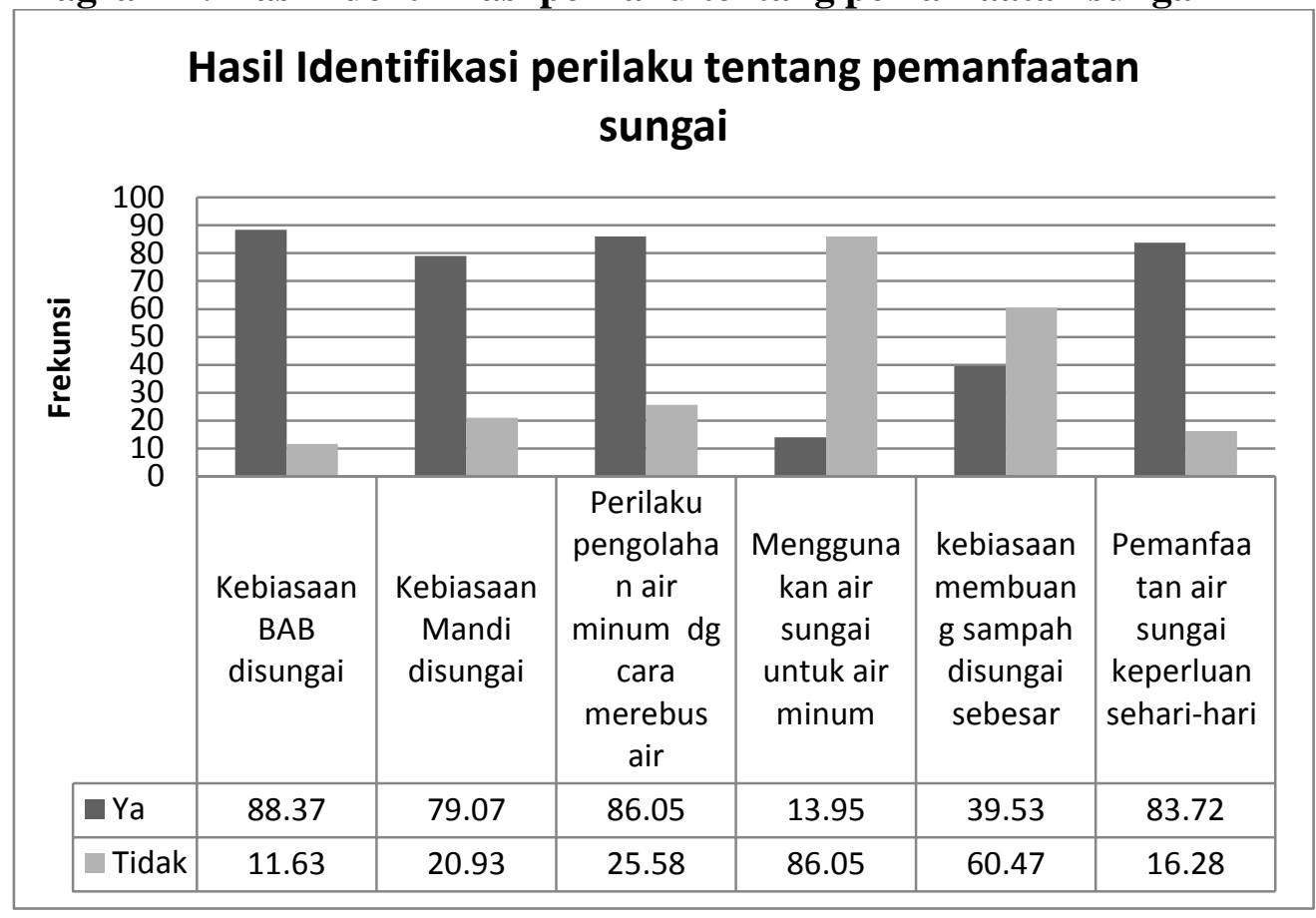

Hasil Identifikasi perilaku tentang pemanfaata sungai menunjukan bahwa kebiasaan buang air besar (BAB) di sungai sebesar $(88,37 \%)$ dilihat padadiagram 2.Ternyata sebagian besar responden tidak memiliki jamban sendiri. Sehingga tinja tidak di kelola dengan baik, dimana tinja merupakan sumber penyakit terutama penyakit diare.Perilaku pengolahan air minum rumah tangga menunjukan merebus air sebesar $86,05 \%$, untuk mendapatkan air minum yang berasal dari air PDAM, Menggunakan air sungai untuk air minum akan tetapi masih terdapat responden yang sebesar $13,95 \%$. Ternyata dari responden masih memiliki kebiasaanmembuang sampah disungai sebesar (39,53\%). Berdasarkan hasil observasi di sepanjang sungai Pekapuran Raya menunjukan banyak tumpukan sampah yang menyebabkan air sungai semakin kotor dan dangkal. Sehingga akan mencemari sungai dan menimbulkan vektor lalat, hal ini akan berpengaruh terhadap penularan penyakit diare. 


\section{Diagnosa pada komunitas berkaitan dengan perilaku ibu mencuci tangan}

Diagram2. Hasil diagnosa komunitas perilaku ibu dalam mencuci tangan

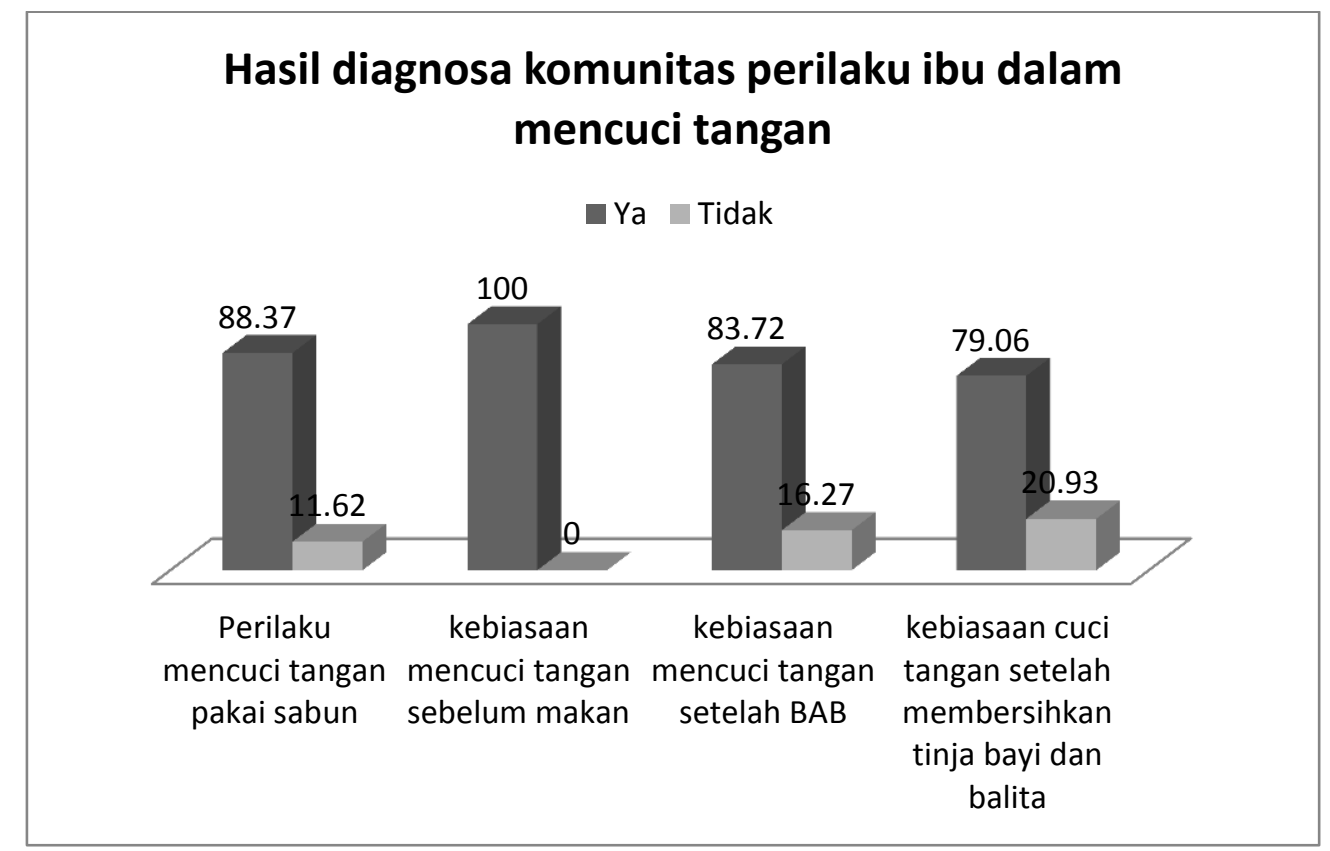

Hasil diagnosa pada komunitas Ibu balita, menunjukkan bahwa perilaku ibu balita masih terdapat $11,62 \%$ yang tidak mencuci tangan dengan sabun, setelah aktivitas keseharian. Sedangkan kebiasaan mencuci tangan setelah BAB terdapat 16,27\% yang belum berperilaku sehat, hal ini terlihat pada diagram 2 . Kebiasaan ibu juga terlihat setelah membersihkan tinja bayi masih terdapat ibu balita yang tidak menggunakan sabun setelah kegiatan tersebut sebesar 20,93\%.

\section{Tindakan perbaikan dan peningkatan keterampilan pencegahan diare}

\section{Manajemen Deteksi Balita Diare $(M D B D)$}

Pemberianmateriedukasipencegahandiaremerupakansalahsatu media informasi yang diberikankepadakomunitasibudengantujuan agar informasi yang diterima lebih mudah dipahami ibu. Materi disampaikan berupa defini, gejala, dampak, resiko bahka data kasus revalensi diare di Pekapuran Raya dan hasil data epidemiologi diIndonesia. Pemberianketerampilanibu balita tentang ManajemenDeteksiBalitaDiarepadaibu balita melalui model EMC. Pengembangan komunitas ibu balita ini sebagai proses yang melibatkan peran ibu untuk mengambil keputusan berkaitan dengan faktor kesehatan yang mempengaruhi perilaku dalam penanganan diare. Proses Penatalaksanan dalam MDBD dibentuk agar ibu memiliki keterampilan, kepercayaan, dan kesiapanan dalam menghadapi pada saat balita terkena diare. Proses Edukasi tergambar sebagaiberikut : 


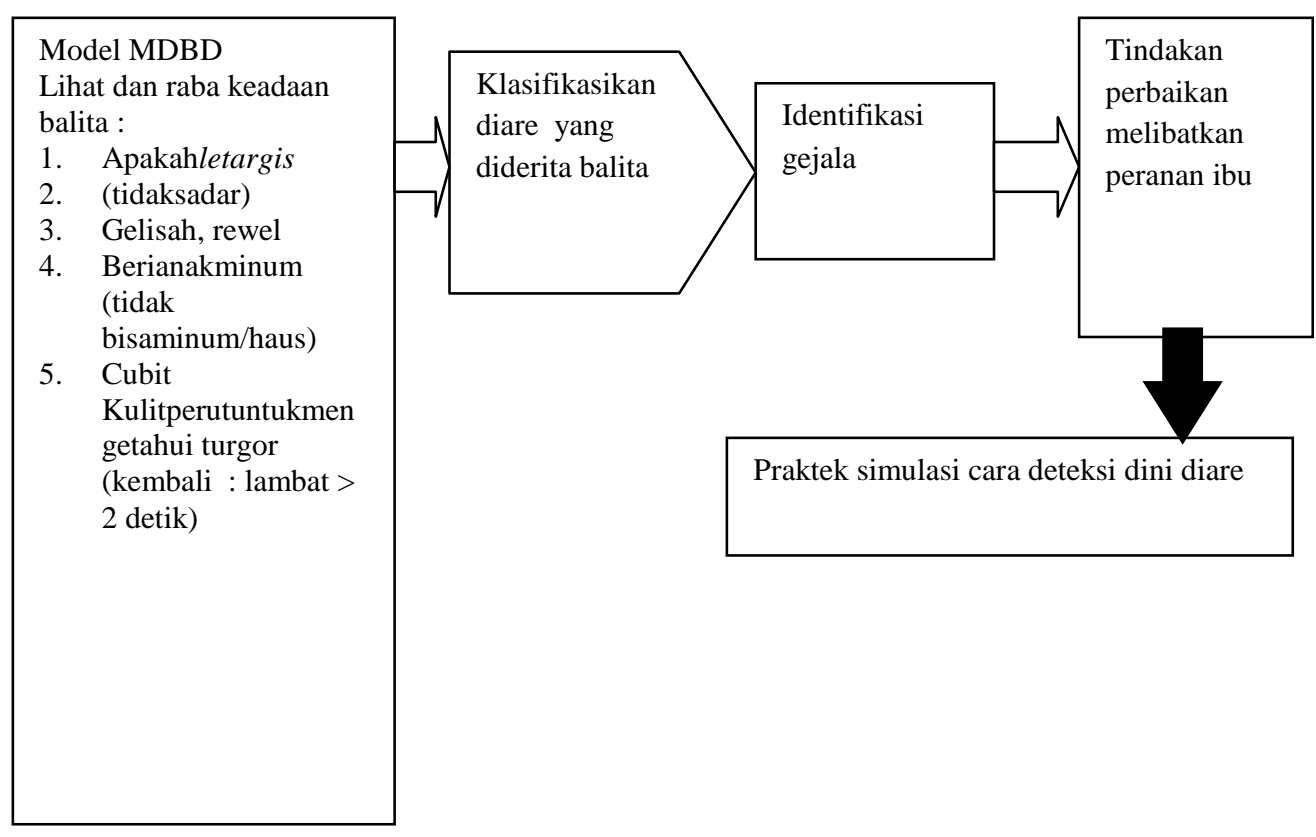

Diagram 1. Pelaksanaan tindakan perbaikan dalam Manajemen Deteksi Balita diare

Implementasi tindakan dalam MDBD dapat dilakukan oleh ibu apabila terdapat anak yang menderita diare. Manajemen pencegahan diare dapat secara langsung diaplikasikan dengan cara lihat dan raba keadaan balita, klasifikasikan diare apakah terjadi dehidrasi atau terdapat darah pada tinja anak, kemudian lakukan identifikasi gejala, jika tidak sembuh dengan pemberian cairan dan pemberian makanan maka tindakan ibu langsung membawa kepelayanan kesehatan terdekat. Padakegiatan Education of the mother Community dilakukan dengan simulasi (roleplay) yang melibatkan kelompok ibu beserta anak balita yang ikut serta pada saat kegiatan. Partisipasi ibu pada saat kegiatan berlangsung sangat antusias, terlihat dari keinginan belajar bersama, mempraktekan tindakan simulasi dan memerankan kondisi saat terjadi diare pada balita. Gambar pelaksanan tersebut seperti kondisi berikutini:

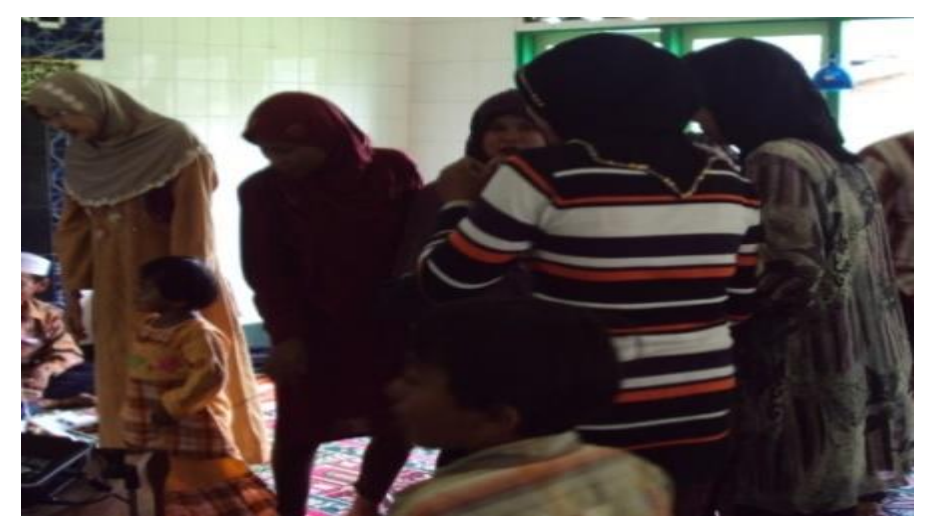

Gambar1. Simulasi (roleplay) dalam MDBD 


\section{Simulasi Peran ibu dalam mengurangi Dehidrasi saat Diare}

Penerapan model EMC yang penting dilakukan juga yaitu pemberian informasi tentang Dehidrasi dan penatalaksanaan diare melalui peningkatan keterampilan ibu membuat Oralit dan Larutan Gula Garam (LGG). Terlaksananya tahapan pencegahan ini dilakukan oleh ibu balita dengan baik melalui kegiatan simulasi peran (roleplay) dimana kelompok ibu mensimulasikan pembuatan oralitdan larutan gulagaram (LGG) dengan tepat.

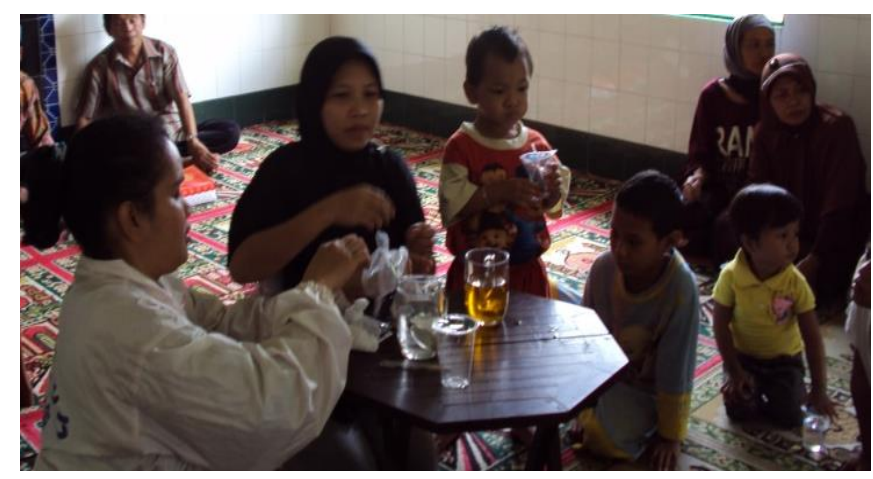

Gambar 2. Simulasi pembuatan oralit dan LGG untuk penatalaksanaan diare

Pemberian cairan merupakan bagian esensial dalam tatalaksana diare untuk menghindari dampak diare terhadap status gizi dan mempertahankan hidrasi. Pencegahan Dehidrasi dilakukan dengan cara penggandaan cairan (rehidrasi), cairan diberikan secara oral untuk mencegah dehidrasi dan mengatasi dehidrasi yang sudah terjadi. Sesuai dengan rekomendasi WHO, penatalaksanaan pemberian cairan pada penderita diare dapat dilihat sebagai berikut:

a. Berikan kepada anak anda cairan lebih banyak dari biasanya untuk mencegah dehidrasi: cairan yang dapat diberikan di rumah adalah larutan garam gula, air tajin, air sayur bayam dll. ASI dan susu formula harus terus diberikan.

b. Bawa anak anda ke petugas kesehatan bila: ketiga tanda ini menunjukkan anak menderita dehidrasi berat jika buang air besar lebih dari 5 kali, sangat haus, Mata menjadi cekung atau kering, Demam, Tidak mau makan atau minum seperti biasa, Kelihatan tidak bertambah baik, Pada tinja terdapat darah.

c. Perlihatkan kepada ibu bagaimana cara mencampur dan memberikan oralit. Tunjukkan kepada ibu berapa banyak oralit yang harus diberikan:

- Umur < 2 tahun: 50-100 ml (1/4-1/2 gelas) setiap BAB.

- Umur 2-5 tahun: 100-200 ml (1/2-1 gelas) setiap BAB.

- Anak-anak yang lebih besar: minum sebanyak mungkin.

d. Bila anak muntah, tunggu 10 menit kemudian pemberian oralit diteruskan tetapi lebih lambat: 1 sendok makan setip 2-3 menit. Berikan kepada ibu oralit untuk 2 hari. 


\section{Diagram 3. Hasil pemanfaatan Oralit untuk Pencegahan diare}

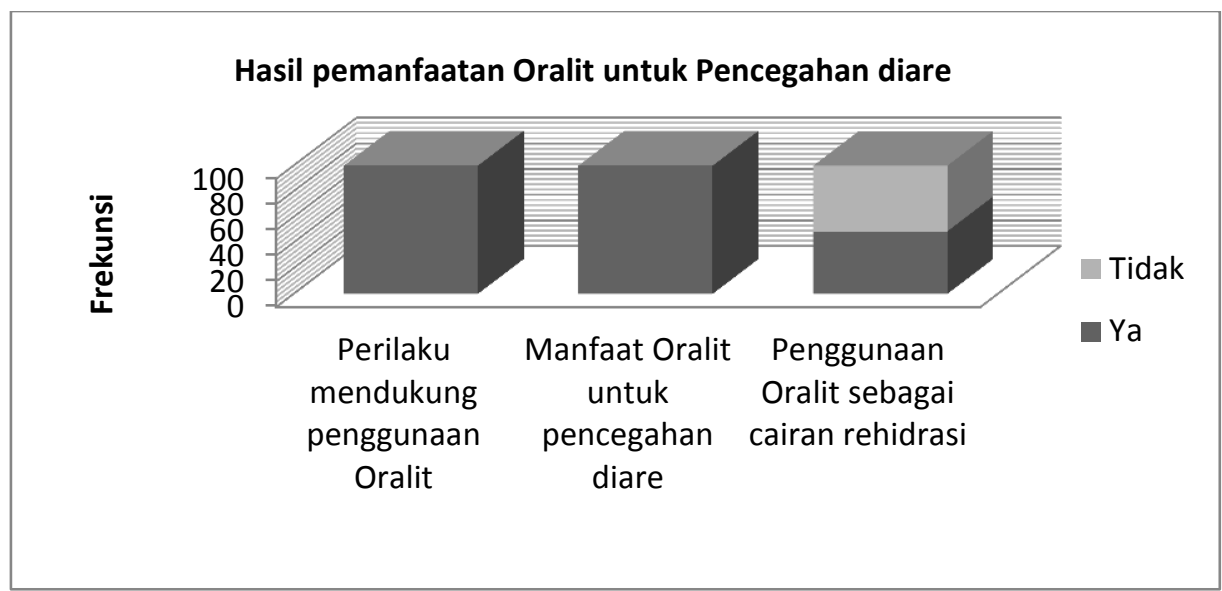

Hasil analisis data berkaitan dengan perilaku Perilaku responden yang mendukung penggunaan Oralit atau cairan rehidrasi oral sebesar $100 \%$ pada penderita saat diare, sebagian tahu tentang manfaat oralit $100 \%$ akan tetapi sebagian besar responden 51,16\% (diagram 3 diatas) menunjukkan bahwa terdapat sebagian ibu balita yang tidak mau menggunakan oralit sebagai cairan rehidrasi di rumah tangga, akan tetapi menggunakan obat tradisional atau obat yang dijual dipasaran.

E. Hasil Rata-rata pengetahuan ibu balita dengan model EMC

Tabel 2. Hasil rata-rata pengetahuan Ibu balita dalam model EMC

\begin{tabular}{lccccl}
\hline Pengetahuan & $\mathbf{n}$ & Rerata \pm SD & Selisih & Ci ;95\% & $\boldsymbol{p}^{*}$ \\
\hline Pre & 43 & $2.81 \pm 0.958$ & 1.37 & $0.970-1.635$ & 0.000 \\
Post & 43 & $4.12 \pm 0.793$ & & & \\
\end{tabular}

* Uji Paired t test

Hasil analisis pada Tabel 2. Menunjukkan bahwa pengetahuan ibudalam pencegahandanpenatalaksanaandiaredi Pekapuran Raya Banjarmasin. Setelah dilakukan pengujian statistik menggunakan Uji paried $t$ testantarapredanpost testuntukpemahamanibubalitadiperolehnilai $\mathrm{p}=0,000 \quad(<\alpha=0,05)$ hal ini berartiterjadiperubahanpemahamansetelahdiberikanmodel pendekatan education of the mother community pada kelompokibu di Pekapuran Raya.

\section{PEMBAHASAN}

\section{A. Model Education of the mother community}

Pelaksanaan kegiatan promosi kesehatan ini menekankan pada model EMC. Model Education of the mother community yaitu suatu pendekatan yang diterapkan untuk memfasilitasi kelompok sasaran terutama ibu-ibu (masyarakat) dalam memahami permasalahan dan potensi peningkatan sanitasi di komunitas ${ }^{(13)}$.Kegiatan EMC ini lebih ditekankan pada perubahan perilaku dan kebiasaan masyarakat dalam penanganan serta pencegahan diare. Kegiatan ini tidak hanya bertujuan untuk meningkatkan pemahaman ini tetapi juga 
berpartisipasi dalam peningkatan keterampilan dan tentang pencegahan diare tetapi diharapkan mampu melakukan manajemen deteksi balita diare (MDBD) secara tepat.

Di masyarakat terdapat berbagai potensi yang bisa dikembangkan untuk melindungi anak dari ancaman penyakit diare yang mempunyai kecenderungan potensial menimbulkan wabah $^{(14)}$. Ancaman kesehatan ini berkaitan dengan pembuangan kotoran (faeces dan urina) di sungai yang tidak menurut aturan dapat membahaya kesehatan terutama anak balita $<$ dari 5 tahun yang rentan terhadap penularan penyakit ini. Penerapan model pendekatan Education of the mother community dalamupaya pencegahan diare di Pekapuran Raya Banjarmasin secara efektif dan menarik diharapkan berpengaruh terhadap keluarga secara optimal. Pelakaksanaan EMC diperlukan komitmen dan kesepakatan kelompok ibu untuk terus belajar mengembangkan pemahaman terkait kondisi dilingkungan komunitas Pekapuran.

Penerapan model education of the mother community (EMC) melalui metode gabungan diskusi, simulasi (roleplay), manajemen deteksi balita diare dan diagnosa educatif dimana responden (kelompok ibu) secara aktif terlibat dalam semua kegiatan sehingga peran ibu dapat lebih optimal dalam pencegahan penyakit diare. Menurut Suhardjo (2003), diskusi melibatkan peran aktif dari peserta untuk memberikan pertanyaaan dan berdiskusi mengenai pengalamannya selama kegiatan berlangsung dapat dipecahkan bersama oleh kelompok yang memungkinkan peserta mengadopsi pemecahan tersebut ${ }^{(15)}$. Hal ini didukung oleh penelitian Yeni, dkk (2009) dimana penggunan gabungan metode diskusi dapat meningkatkan pengetahuan orang tua tentang pengaturan pola makan balita ${ }^{(16)}$.

Perilaku masyarakat yang negatif yang dapat meningkatkan jumlah penyebaran kuman diare menjadikan konsep diagnosa edukatif penting diterapkan. Dasar penilaian perilaku negatif ini dilihat dari kebiasaan cuci tangan, BAB disungai, perilaku pengolahan air, kebiasaan buang sampah disungai. Berdasarkan kajian WHO, cuci tangan memakai sabun dapat mengurangi angka diare hingga $47 \%^{(8)}$. Menurut Sutarja (2005) menyatakan bahwa ada hubungan perilaku mencuci tangan sebelum amakan dengan kejadian diare ${ }^{(17)}$.

Hasil penelitian ini juga didukung oleh kumarijati (2006) dan Suprapti (2003) bahwa ada hubungan perilaku konsumsi air yang sudah dimasak dengan kejadian diare ${ }^{(18)}$. Sedangkan menurut Eman (2008) kebiasaan memasak atau merebus air sampai benar-benar mendidih untuk memastikan air sudah steril adalah salah satu alternatif penting dalam mencegah penyakit diare karena ditemuakan bahwa dalam 1 gr tinja mengandung 10 juta virus dan 1 juta bakteri(19) . Menurut Rolandus (2010) menyatakan bahwa ada pengaruh perilaku mengkonsumsi air sungai terhadap kejadian diare dapat dikatakan bahwa orang yang mengkonsumsi air minum yang belum dimasak memiliki resiko 2,625 kali lebih besar untuk terkena diare dibandingkan orang yang mengkonsumsi air yang sudah masak ${ }^{(20)}$.penelitian ini berbeda dalam pengguaan obat diare yakni sebesar $51,16 \%$ belum memanfaatkan oralit sebagai pengobatan. Berbeda dengan Hasil survei morbilitas kejadian diare tercatat bahwa pengobatan diare dengan cara diberikan oralit sebanyak 188 orang $(37,0 \%), 159$ orang $(31,30 \%)$ diberikan obatobatan, 128 orang $(25,20 \%)$ tidak diberikan apa-apa, 38 orang $(7,48 \%)$ diberikan ramuan/jamu, 37 orang $(7,28 \%)$ diberi LGG dan 29 orang $(5,71 \%)^{(4)}$. 
Banyak masyarakat menganggap bahwa diare merupakan penyakit biasadan sering terjadi sehingga menganggap remeh penyakit ini, Namun jika sudah gawat seringkali berakibat fatal terhadap penderita, karena keterlambatan penanganan yang tepat penderita diare, hal ini diakibatkan karena masih banyak masyarakat yang belum menerapkan prinsip-prinsip rehidrasi seawal mungkin sehingga terjadi keterlambatan tindakan rehidrasi yang dapat memperparah kesakitan, bahkandapat mengakibatkan kematian.

Metode ini juga memiliki keunggulan yakni lebih menarik digunakan dalam kegiatan promosi kesehatan karena berbagai macam motivasi dan mengembangkan kegiatan yang dikombinasi seperti simulasi peran, pemetaan atau mapping kondisi lingkungan untuk mengidentifikasi permasalahan, pembelajaran dalam bentuk materi diare yang disajikan sesuai data dan fakta dilapangan maupun melihat kondisi keseharian masyarakat. Proses belajar melalui media ini dapat membangkitkan fikiran dan kreatif akhirnya dapat merangsang partisipasi ibu untuk terus aktif dalam menerima materi pembelajaran.

\section{Peningkatan pemahaman ibu balita pre-postPenerapan Model EMC}

Berdasarkan Hasil uji analisis statistik menggunakan uji pairedttestdengan $\alpha=0.05$ pada pre test dan post testdidapatkan peningkatan secara signifikan, artinya terdapat perbedaan sebelum dan setelah intervensi menggunakan penerapan model Education of Mother Community (EMC), efektif atau bermanfaat sebagai media informasi dan promosi kesehatan $(p<0,05)$. Terjadinya perubahan nilai tersebut karena responden telah memahami model dan materi yang disampaikan.

Uji beda rerata selisih hasil pre test-post test menggunakan model EMC menunjukkan perbedaan signifikan. Peningkatan skor rata-rata selisih tingkat pengetahuan tentang komplikasi sebesar 1.37 pada tabel 5. Metode ini memberikan informasi kesehatan, motivasi perilaku hidup bersih dan sehat serta anjuran dalam pencegahan diare melalui kegiatan Manajemen Balita Deteksi Diare yang baik bagi ibu balita. Penelitian serupa juga dilakukan oleh Elly Swandewi, dkk menyebutkan bahwa penerapan model promosi kesehatan menggunakan peer education pada kelompok Dasawisma sebagai upaya penemuan tersangka penderita TB Paru efektif meningkatkan pengetahuan, hasil pengukuran pre dan post test dengan menunjukkan bahwa selisih peningkatan sebesar 3.34 sebelum dan setelah perlakuan 1 sebesar 4.76 dan setelah 1 bulan intervensi diukur kembali dengan nilai selisih sebesar 1.42 bermakna secara statistik $^{(21)}$.

Hasil temuan diatas berarti bahwa keputusan untuk memilih metode yang akan dipakai harus disesuaikan dengan permasalahan dan sasaran yang diberikan, keefektifan suatu metode dapat dilihat dari kriteria kemudahan program promosi yang dibuat, tepat sasaran dan cepat penyajian informasi ditampilkan serta aspek pembiayaan. Beberapa metode dapat dikombinasikan untuk mempermudah penyampaian promosi kesehatan seperti penggunaan motode ceramah, diskusi kelompok, penyuluhan disertai dengan pemutaran video bergambar, agar informasi tentang bahaya, tanda dan gejala terjadinya diare lebih mudah dipahami oleh ibu, sehingga ibu dan balita sehat terhindar dari diare. 
Berdasarkan analisis dapat disimpulkan bahwa peningkatan nilai rerata pengetahuan ibu pre dan post test terdapat perbedaan bermakna secara statistik. Artinya ibu menyadari bahwa materi pencegahan diare dalam diagnosa edukatif penting dan menarik sebagai bentuk upaya peningkatan pemahaman dalam penatalaksanaan diare yang dapat terjadi pada balita. Menurut Rogers mengungkapkan bahwa sebelum seseorang mengadopsi perilaku baru dalam diri orang tersebut menjadi proses berurutan yakni adanya kesadaran pentingnya mengetahui pesan yang disampaikan, kemudian menimbang-nimbang tentang materi pesan yang disampaikan, jika materi tersebut tepat dan baik akan direspon dengan tindakan mencoba baru berperilaku sesuai informasi yang diperoleh atau mengadopsi pesan yang dianjurkan ${ }^{(22)}$.

\section{KESIMPULAN}

Berdasarkan hasil penelitian ini disimpulkan bahwa Penerapan model educationof the mother community (EMC) dapat meningkatkan peran ibu dalam pencegahan penyakit diare di Pekapuran Raya Banjarmasin. Model ini terbukti bermanfaat untuk menyampaikan informasi kesehatan berhubungan denganpencegahan diare pada balita, hal ini terlihat dari keterampilan ibu Balita dalam penatalaksanaan diare secara tepat dan benar melalui manajemen deteksi balita diare, simulasi Oralit serta mampu mediagnosa lingkungan serta terdapatpeningkatan pengetahuan ibu balita setelah dilakukan kegiatan $\operatorname{EMC}(\mathrm{p}<0,05)$.

\section{SARAN}

Penting penelitian lebih lanjut terkait pengembangan dan implementasi model pendekatan Education of mother community sebagai media promosi kesehatan dengan kajian penyakit yang berbeda untuk melihat kecenderungan kemanfaatan serta alternatif pemecahan masalah kesehatan dimasyarakat.

\section{UCAPAN TERIMAKASIH}

Ucapan Terimakasih dan penghargaan kepada Tim Pengabdian Masyarakat Program Studi Kesehatan Masyarakat Universitas Lambung Mangkurat, yang telah membantu terlaksananya seluruh kegiatan, serta Dinas Kesehatan, Puskesmas, Camat, Lurah Pekapuran Raya atas bantuan dan kerjasama yang diberikan.

\section{DAFTARPUSTAKA}

1. Adisasmito, Wiku, 2007. Faktor Risiko Diare Pada Bayi dan Balita Di Indonesia: Systematic Review Penelitian Akademik Bidang Kesehatan Masyarakat. Depok: Universitas Indonesia. Makara, Kesehatan, Vol. 11, No. 1, Juni 2007: 1-10

2. Hiswani, 2007. Diare Merupakan Salah Satu Masalah Kesehatan Masyarakat Yang Kejadiannya Sangat Erat Dengan Keadaan Sanitas $i$ Lingkungan. SumateraUtara : FKM Universitas SumateraUtara. 
3. Kasnodihardjo,dkk, 2007. Gambaran Perilaku Penduduk Mengenai Kesehatan Lingkungan Di Daerah Pedesaan Subang, JawaBarat. http://google.com Diakses 13 Februari 2007.

4. WHO, 2017. Sekitar 35 juta balita masih beresiko jika target angka kematian anak tidak tercapai. www.unicef.org/indonesia.

5. Kementerian Kesehatan, 2011. Situasi diare di Indonesia. Jendela data di Indonesia.http://www.kemkes.go.id/

6. Dinas Kesehatan, 2008. Laporan Tahunan Dinas Kesehatan Provinsi Kalimantan Selatan tahun 2008. Banjarmasin : Dinas Kesehatan Kalimantan Selatan

7. DepartemenKesehatan RI, 2008. Penyebab Kematian Telah Bergeser Dari Penyakit Menular.Jakarta : Pusat data dan informasi Departenmenkes RI

8. Anonymaus. 2009. Diare mewabah di Kalimantan Selatan. Banjarmasin. Penerbit Cetak berita. Banjarmasin Post.

9. Kuswandjana. 2004. Demam Berdarah dan Diare Terus menyerang warga diberbagai daerah. Jakarta 2004. http:// www. Ibatan.com. diakses 7 maret 2007.

10. Anonim, 2007. Banjarmasin Terkotor, 420 Meter $^{3}$ Sampah Telah Terangkat KCM. Forum Walhi. http://wwwkompas.com.diakses 27 September 2007.

11. Rudi Rakhmady dan Gurendro, 2005. Beberapa Faktor Yang Berhubungan Dengan Praktek Penatalaksanaan Diare Ibu Rumah Tangga Di Puskesmas Kedanean Kabupaten Gresik. Bidang penelitian dan Pengembangan RSU Dr Soetomo 2005.7 (4);145-149.

12. Anonim, 2004. Kota Seribu Sungai Seribu Masalah. Forum Walhi. http://info@walhi.or.id.diakses tanggal 04 oktober 2004.

13. Muhlisin, Ahmad, 2004. Kualitas Bakteriologi Air dan Perilaku Kesehatan Di Kecamatan Banjarmasin Utara ;Dalam Kaitan Angka Kejadian Diare : Penelitian Observasional Laboratoris. Surabaya :AirlanggaUniversity.

14. Gertruida, T. Surahni, Ninik S, Sukowidodo,1990. Laporan Pelaksanaan KomunikasiProgram P2 Diare di Indonesia. Jakarta :Pusat Penyuluhan Kesehatan MasyarakatDep.Kes. RI

15. Suhardjo, 2003. Berbagai Cara PendidikanGizi. Jakarta :BumiAksara.

16. Yeni Y. B, dkk. Pengaruh gabungan metode diskusi dan simulasi terhadap perilaku ibu dalam pengaturan pola makan batita. Di kelurahan karangsiri Kabupaten timur tengah Selatan. Jurnal Pangan Gizi dan kesehatan Vol 2 No 1. April 2010. Diterbitkan FKM Universitas Nusa Cendana. Hal 179-184.

17. Suprapti, 2003. Hubungan Kualitas Sumber Air Minum dan Pengelolaannya dengan Kejadian Diare pada Balita di Kelurahan Kuripan Kecamatan Karawangen Kabupaten Demak 2003.Skripsi. Yogyakarta: FKM UNDIP www.fkm.undip.ac.id

18. Kasduki, 2005. Hubungan Antara Penanganan Awal Diare Dengan Kejadian Dehidrasi Pada Balita Di Ruang Menular Anak RSU DR. Soetomo Surabaya. Bidang penelitian dan pengembangan RSU Dr Soetomo 2005. 7 (3): 100-104. 
19. Eman, T., 2008. Cara Aman Konsumsi Air Minum. Jakarta : Republika Online, www.Gizi.net.com.

20. Rolandus V. Agas, dkk, 2009. Hubungan Perilaku Masyarakat dan Sanitasi Sumur Gali Terhadap Kejadian Diare Di Keluarahan Belo Wilayah KerjaPuskesmas Sikauman Kota Kupang. Undana : FKM.

21. Murti Elly Swandewi, Yayi Suryo Prabandari, B. S. R. (2006). Efektivitas promosi kesehatan dengan peer education pada kelompok dasawisma dalam upaya penemuan tersangka penderita TB Paru. Berita Kedokteran Masyarakat, BKM/XXI/03 (health promotion), 1-7.

22. Notoatmodjo. (2007). Promosi kesehatan dan Ilmu Perilaku (pertama., pp. 171-202). Jakarta: Penerbit PT Reneka Cipta. 